Loyalitas Kreativitas

Aldi Masyarakat Kreatif
P-ISSN 2722-2101, E-ISSN 2722-4201

Program Studi Ekonomi Manajemen Universitas Pamulang

Jurnal LOKABMAS Kreatif Vol.02,No.01,Maret 2021 Hal. 1-7

Email:jurnalkreatif.manajemen@gmail.com

\title{
MANAJEMEN KREATIVITAS UNTUK MENINGKATKAN PRODUKTIVITAS MASYARAKAT KELURAHAN PONDOK BENDA
}

Muliahadi Tumanggor, Waluyo Jati, Eti Ariyanti, Gitayana Amalia, Rino Dedi Aringga.

\author{
Dosen Ekonomi Fakultas Ekonomi Akutansi Universitas Pamulang \\ Email dosen00871@unpam.ac.id, dosen00565@unpam.ac.id, dosen02302@unpam.ac.id, \\ dosen02173@unpam.ac.id, dosen02171@unpam.ac.id.
}

\begin{abstract}
ABSTRAK
Manajemen Inovasi adalah kombinasi dari manajemen dari proses inovasi dan manajemen perubahan.Manajemen inovasi memungkinkan organisasi untuk menanggapi peluang eksternal atau internal dan menggunakan kreativitas untuk memperkenalkan ide-ide, proses, atau produk. Suatu organisasi agar bisa bersaing dengan organisasi lain maka perlu melalukan inovasi secara terus-menerus dalam berbagai aspek, baik produk, layanan, proses kerja, metode maupun lainnya. Salah satu modal untuk melakukan inovasi adalah adanya kreativitas. Keterkaitan antara keduanya yaitu kreativitas merupakan pengembangan ide-ide baru sedangkan inovasi adalah proses penerapan ide-ide tersebut secara aktual ke dalam praktek. Kreativitas merupakan interaksi antara potensi individu dengan lingkungan. Agar kreativitas berkembang di organisasi maka ada beberapa upaya yang dilakukan yaitu curah pendapat di dalam tim/kelompok kerja, gaya kepemimpinan yang mendorong kreativitas meliputi pengampilan keputusan partisipati, kepemimpinan transformasional, high exchange dan mengmbangkan kultur kreatif Supaya PKM ini tepat sasaran, maka perlu diperhatikan metode pelaksanaan PKM. Adapun metode pelaksanaan PKM ini adalah dengan cara: Dalam melaksanakan kegiatan PKM ini digunakan beberapa metode yaitu: 1. Metode Ceramah / Presentasi, 2. Metode Tanya Jawa. 3. Sharing Session. Tentang meningkatkan peran ibu rumah tangga dalam pengelolaan keuangan. Sharing session ini diberikan kepada para peserta guna mendorong membimbing masyarakat setempat kelurahan pondok benda. Adapun hasil dari PKM ini nantinya akan dievaluasi berdasarkan taraf penyelesaian materi pelatihan, dan selanjutnya tim kegiatan PKM akan melakukan evaluasi tersebut dengan mengamati dan memeriksa metode pelaksanaan yang sudah dirancang dan yang telah diberikan kepada masyarakat di kelurahan Pondok Benda sebagai peserta.
\end{abstract}

Kata Kunci: Manajemen, Kreativitas, dan Produktivitas.

\begin{abstract}
Innovation management is a combination of management of the innovation process and change management. Innovation management enables organizations to respond to external or internal opportunities and use creativity to introduce ideas, processes, or products. In order to be able to compete with other organizations, an organization needs to carry out continuous innovation in various aspects, be it products, services, work processes, methods or others. One of the assets for innovation is creativity. The relationship between the two is that creativity is the development of new ideas while
\end{abstract}


Loyalitas Kreativitas

Aldi Masyarakat Kreatif
P-ISSN 2722-2101, E-ISSN 2722-4201

Program Studi Ekonomi Manajemen Universitas Pamulang

Jurnal LOKABMAS Kreatif Vol.02,No.01,Maret 2021 Hal. 1-7

Email:jurnalkreatif.manajemen@gmail.com

innovation is the process of actually applying these ideas to practice. Creativity is an interaction between individual potential and the environment. In order for creativity to develop in organizations, there are several efforts made, namely brainstorming in teams / work groups, leadership styles that encourage creativity including participatory decision skills, transformational leadership, high exchange and developing a creative culture In order for this PKM to be right on target, it is necessary to pay attention to the method PKM implementation. The method of implementing this PKM is by: In carrying out this PKM activity, several methods are used, namely: 1. Lecture / Presentation Method, 2. Javanese Questioning Method. 3. Sharing Session. About increasing the role of housewives in financial management. This sharing session was given to the participants to encourage guiding the local community in Pondok Benda village. The results of this PKM will later be evaluated based on the level of completion of the training material, and then the PKM activity team will carry out the evaluation by observing and examining the implementation methods that have been designed and that have been given to the community in Pondok Benda village as participants.

\section{Keywords: Management, Creativity, and Productivity.}

\section{PENDAHULUAN}

Perekonomian yang berdaya inovasi mampu menghasilkan nilai tambah yang unik dan substansial bagi masyarakat dan pada gilirannya berimbas positif kepada pelakupelaku perekonomian dan seluruh perekonomian. Dewasa ini, dengan sistem perekonomian yang sangat terbuka maka dampak daya-daya inovasi dan keberhasilan inovasi suatu perekonomian akan berimbas pada perekonomian lain. Fontana,A.(2011:2) menjelaskan terdapat beberapa hal penting dalam artikel-artikel terbaru Harvard Business Review (October 2008). Pertama, pentingnya inovasi pada dunia dewasa ini dan masa mendatang; proses penciptaan nilai seharusnya dilakukan dengan lebih banyak melibatkan konsumen/pengguna sebagai kontributor.Kedua, kreativitas harus menjadi preokupasi manajemen puncak dalam memimpin bisnis dewasa ini dan masa mendatang serta organisasi membutuhkan pergeseran gaya memimpin dan mengelola (inovasi dibangun dengan kreativitas sebagai salah satu pilar). Ketiga, praktis manajemen perlu dirancang.

Mayoritas masyarakat telah mengakui dan berlomba-lomba untuk menciptakan citra daerah yang lebih baik, tidak lain dalam kreatifitas dan inovasi yang berbasis ekonomi maupun budaya. Citra daerah merupakan sebuah identitas, simbol yang menjadi daya tarik menjadikan manusia terbawa kedalam fikiran untuk menggambarkan (imajinasi) sebuah daerah yang memiliki kelebihan dari daerah lain baik yang berkaitan dengan wisata, produk kerajinan ataupun kretifitas yang lainya. Disadari atau tidak masyarakat kreatif ini sering kita jumpai dalam semua lapisan masyarakat entah itu seniman, mahasiswa, sastrawan, wirausahawan atau konspetor-konseptor di bidang pariwisata dan organisasi-organisasi kemasyarakatan yang memiliki daya lebih dalam membuat ide-ide dan gagasan untuk membangun daerah, dunia mengakui pada hakikatnya masyarakat Indonesia memiliki kelebihan yaitu gotong royong dan semangatnya dalam inovasi dan kreatifitas. seperti yang dikemukakan oleh Trompenaar dan HamdenTurner (1998) dimana orang Indonesia cenderung menempatkan kepentingan kelompok daripada kepentingan individu, bisa diartikan bahwasanya masyarakat Indonesia menjunjung tinggi kepentingan bersama. Mengenal masyarakat kreatif, sebelum membahas lebih jauh alangkah baiknya mari kita definisikan apa itu kreatif? Menurut Zimmerer dkk. (2009) kreatif adalah kemampuan untuk mengembangkan ide-ide baru dan untuk menemukan cara-cara baru dalam melihat masalah dan dan peluang, masyarakat kreatif ini orang-orang yang memiliki ide dan gagasan untuk menemuka cara untuk menjawab sebuah masalah dengan keahlian di bidang masing-masing, baik dalam konteks budaya, ekonomi dan sosial. 
Loyalitas Kreativitas Aldi Masyarakat Kreatif
P-ISSN 2722-2101, E-ISSN 2722-4201

Program Studi Ekonomi Manajemen Universitas Pamulang Jurnal LOKABMAS Kreatif Vol.02,No.01,Maret 2021 Hal. 1-7 Email:jurnalkreatif.manajemen@gmail.com
Ini merupakan bagian kecil dari masyarakat-masyarakat kreatif yang telah muncul dari permukaan, masih banyak lagi masyarakat-masyarakat kreatif yang perlu di gali dan di dukung oleh pemerintah daerah, bahkan pejabat desa yang menjadi ujung tombak peradaban. Permasalahanya dalam sebuah sistem kemasyarakatan di batasi dan didukung oleh sebuah peraturan, memang bahwa di era pemerintahan sekarang kreatifitas memiliki dukungan dari pemerintahan pusat sebagai contoh di bidang ekonomi yang kita kenal dengan ekonomi kreatif hadirnya Perpres No 142 Tahun 2018 Tentang Rencana Induk Pengembangan Ekonomi Kreatif Nasional Tahun 2018-2025 dalam pasal 8 menjelaskan dari jajaran menteri hingga Bupati ikut berperan dalam mengembangkan ekonomi kreatif, agar bisa menyentuh dan mengembangkan kreatifitas di tingkat masyarakat desa.

Kreativitas yang ada pada individu digunakan untuk menghadapi berbagai permasalahan yang ada ketika berinteraksi dengan lingkungannya dan mencari berbagai alternatif pemecahannya sehingga dapat tercapai penyesuaian diri secara adekuat (Asrori,M.,2008:62). Torrance (1981) menjelaskan kreativitas adalah proses kemampuan individu untuk memahami kesenjangan-kesenjangan atau hambatanhambatan dalam hidupnya, merumuskan hipotesis-hipotesis baru dan mengkomunikasikan hasil-hasilnya serta sedapat mungkin memodifikasi dan menguji hipotesis-hipotesis yang telah dirumuskan. Agar dapat melakukan semua itu memerlukan dorongan-dorongan dari lingkungan yang didasari oleh potensi-potensi kreatif yang telah dimiliki sehingga dapat mempercepat berkembangnya kreativitas pada individu (Asrori,M.,2008:65).

\section{RUMUSAN MASALAH}

Adapun rumusan masalah dalam PKM ini adalah:

1. Bagaimana masyarakat di Kelurahan Pondok Benda?
2. Bagaimana manajemen kreativitas masyarakat di Kelurahan Pondok Benda?

3. Bagaimana produktivitas masyarakat di Kelurahan Pondok Benda?

\section{TUJUAN PELAKSANAAN}

Adapun tujuan dari kegiatan Pengabdian Kepada Masyarakat adalah:

1. Untuk mengetahui masyarakat di Kelurahan Pondok Benda.

2. Untuk mengetahui manajemen kreativitas masyarakat di Kelurahan Pondok Benda.

3. Untuk mengetahui produktivitas masyarakat di Kelurahan Pondok Benda.

\section{TINJAUAN PUSTAKA}

Manajemen merupakan proses penting dalam suatu organisasi atau perusahaan. Dengan menggunakan manajemen yang baik, maka tujuan perusahaan dapat tercapai sesuai rencana yang ditetapkan. Menurut Malayu S.P. Hasibuan (2012) mengatakan bahwa manajemen adalah ilmu dan seni yang mengatur proses pemanfaatan sumber daya manusia dan sumber-sumber lainnya secara efektif dan efisien untuk mencapai tujuan tertentu.

Pengertian
Jawwad,AA.(2004:3) menjelaskan artivitas kreativitas secara etimologis adalah memunculkan sesuatu yang baru tanpa ada contoh sebelumnya. Suatu produk yang dikategorikan kreatif akan memenuhi sifatsifat baru dan unik pada formasi finalnya, meski unsur-unsur dasar memang sudah ada sebelumnya. Para pakar lain mendefinisikan bahwa kreativitas adalah proses yang menghasilkan karya baru serta memungkinkan diaplikasikan baik dalam bidang keilmuan, keseniaan, kesusastraan maupun bidang lainnya. Munandar,U.(1992) mendefinisikan kreativitas adalah kemampuan yang mencerminkan kelancaran, keluwesan, dan orisinalitas dalam berpikir serta kemampuan untuk mengelaborasi suatu gagasan. Lebih lanjut dijelaskan bahwa kreativitas sebagai keseluruhan kepribadian sebagai hasil interaksi 
Loyalitas Kreativitas Aldi Masyarakat Kreatif
P-ISSN 2722-2101, E-ISSN 2722-4201

Program Studi Ekonomi Manajemen Universitas Pamulang

Jurnal LOKABMAS Kreatif Vol.02,No.01,Maret 2021 Hal. 1-7

Email:jurnalkreatif.manajemen@gmail.com dengan lingkungannya. Lingkungan tempat individu berinteraksi dapat mendukung berkembangnya kreativitas tetapi juga menghambat dapat menghambat berkembangnya kreativitas.

Karakteristik Kognitif Untuk Berpikir Kreatif Bowd, McDougall dan Yewchuck (1994) menjelaskan ciri-ciri aspek kognitif yang diperlukan untuk menghasilkan pemikiran kreatif yang meliputi : (1) Fluency: kelancaran menjawab pertanyaan; Flexibility: mampu menghasilkan gagasan yg tdk biasa; (3) Originality: mampu melihat dari sudut pandang yang berbeda dan mampu menghasilkan gagasan yang original; (4) Elaboration: mampu mengelaborasi konsep dan mengimplementasikan; (5) Visualization: mampu berimajinasi dan memvisualisasikan konsep; (6) Transformation: mampu mengubah suatu benda/gagasan pada benda/obyek lain dan melihat makna \& manfaat dgn cara baru; (7) Intuition: kemampuan melihat hub./kaitan suatu hal dgn hal lain dalam kondisi informasi terbatas dan (8) Synthesis: kemampuan mengkombinasikan bagianbagian ke dalam keseluruhan yang kompak dan logis (Ancok,D,2012:68).

Ciri-Ciri Pribadi Yang Kreatif West,M.A.(2000:36-39) memaparkan bahwa salah satu cara untuk mengembangkan kreatifitas adalah mengembangkan sejumlah kualitas pribadi yang telah diidentifikasikan berulang-ulang sebagai ciri-ciri orang yang secara konsisten kreatif, meliputi:(1) ketertarikan pada kegiatan yang bernilai intelektual dan artistik;(2) ketertarikan untuk memahami masalah yang kompleks untuk menemukan solusi; (3) memiliki kepedulian pada proses dan pencapaian hasil kerja yang sebaik-baiknya; (4) menunjukkan ketekunan dalam pencapaian tujuan;(5) memiliki pemikiran yang mandiri; (6) menunjukkan toleransi terhadap situasi/masalah yang ambigu; (7) memiliki kebutuhan otonom/kebebasan;(8) memiliki kepercayaan diri; (8) memiliki kesiapan mengambil resiko. Menghasilkan Kreativitas Berbasis Potensi Diri Musrofi, M. (2007:1) menjelaskan bahwa setiap manusia diberi karunia potensi atau bakat. Manusia seharusnya bersyukur terhadap karunia potensi/bakat yang telah diberikan Sang Pencipta Allah SWT. kepada dirinya. Hakikat bersyukur menurut Quraish Shihab adalah menampakkan nikmat sesuai kehendak pemberi, juga menyebut-nyebut dengan baik.

Cara mensyukuri nikmat bakat atau potensi diri yaitu : (1) merenungi dan mengenali potensi diri atau bakat yang sesungguhnya ada dalam diri kita; (2) memfokuskan diri pada bakat tersebut dengan secara terus-menerus melatih dan memanfaatkan bakat itu sebagai realisasi tugas kekhalifahan dimuka bumi (Musrofi, M., 2007:3-4). Musrofi (2007) dalam bukunya Lima Langkah Melahirkan Mahakarya : Melejitkan Potensi Diri dengan Cara Membiasakan Berkarya memaparkan lima langkah untuk berkarya yang bersumber pada potensi diri. Lima langkah tersebut meliputi : (1) memahami arti penting potensi diri atau bakat; (2) mengenal potensi diri; (3) mengungkap ide-ide karya dari potensi diri; (4) membuat prioritas ide karya; (5) merencanakan dan berkarya. Tiap-tiap langkah diuraikan sebagai berikut. Pertama, memahami arti penting potensi diri atau bakat. Bakat /potensi merupakan fasilitas Allah Swt. agar manusia dapat berperan sebagai khalifah di muka bumi.Hal tersebut harus disyukuri dengan cara mengaktualisasikan dan mengoptimalkan bakat/potensi untuk kepentingan sesama. Kedua, mengenal potensi diri. Beberapa cara untuk mengenal potensi diri antara lain yaitu a) mengenali kegiatan yang disukai dan menyenangkan bagi diri sendiri. Aktifitas yang disukai kemungkinan merupakan cermin potensi diri; b)mengenali aktifitas yang mengasikkan, sehingga tidak merasa telah melakukan aktifitas tersebut berjam-jam. Ketika sedang mengungkapkan potensi diri, kita cenderung masuk ke dalam kondisi mengalir;c) mengenali aktifitas yang biasanya mudah dan cemerlang dilakukan; d) mengenali aktifitas impian atau imajinasi yang belum terealisasi; e) menanyakan kepada orang terdekat mengenai bakat/potensi yang kita miliki; f) mengenali aktifitas yang mudah dan cepat untuk dipelajari. Beberapa cara tersebut diharapkan dapat memberikan informasi dan 
Loyalitas Kreativitas Aldi Masyarakat Kreatif
P-ISSN 2722-2101, E-ISSN 2722-4201

Program Studi Ekonomi Manajemen Universitas Pamulang Jurnal LOKABMAS Kreatif Vol.02,No.01,Maret 2021 Hal. 1-7 Email:jurnalkreatif.manajemen@gmail.com kesimpulan mengenai potensi diri seseorang. Ketiga, mengungkap ide-ide karya dari potensi diri. Pada tahap ini seseorang diminta untuk mengeluarkan ide-ide karya dari potensinya sebanyak-banyaknya secara kuantitas. Tony Buzan menjelaskan bahwa otak manusia tidak seperti komputer yang berpikir runtut dan linier, tetapi otak manusia berpikir memancar dan eksplotif.

Mind Map yang dikenalkan Tony Buzan meniru cara kerja otak tersebut. Mind Map dapat digunakan untuk menggali ide sebanyak-banyaknya. Keempat, membuat prioritas ide karya. Banyaknya ide-ide yang telah diungkapkan tentunya tidak semua dapat direalisasikan,sehingga perlu menentukan prioritas ide. Kriteria membuat prioritas ide dapat didasarkan pada keunikan ide; kesegeraan untuk dapat diwujudkan; atau yang paling banyak dimanfaatkan orang lain. Selanjutnya dilakukan : (1) Menentukan dasar kriteria dan kriteria dikelompokkan menjadi tiga, misal banyak dimanfaatkan (kategori A), cukup dimanfaatkan (kategori B), kurang dimanfaatkan (kategori $\quad$ C); (2) Mengelompokkan ide-ide sesuai dengan kategori yang telah dibuat; (3) Mendaftar ide-ide yang termasuk dalam kelompok A, misal kategori ide yang banyak dimanfaatkan;(4) Ide-ide dalam kelompok A dapat dirinci lagi untuk dipilih sebagai prioritas ide karya. Kelima, merencanakan dan berkarya. Apabila sudah ditentukan prioritas ide karya maka perlu membuat rencana. Inti rencana berisi edua hal, yaitu tujuan dan cara mencapainya.

Beberapa hal yang direncanakan meliputi : (1) merumuskan tujuan, yakni ide karya yang akan diwujudkan; (2) merumuskan target waktu penyelesaian; (3) merumuskan langkah-langkah yang dilakukan agar ide karya terselesaikan; (4) menemukan tokoh anutan dan pembimbing dan (5) menentukan tempat berkarya dan menuliskan alat atau fasilitas yang diperlukan. Selanjutnya rencana yang telah dirumuskan hendaknya dilakukan karena rencana sebagus apa pun tanpa disertai tindakan tidak ada artinya. Beberapa hal yang perlu dilakukan agar rencana dapat direalisasikan yaitu (1) menyisihkan waktu dua jam dalam sehari untuk berkarya;(2) Selalu mengingat Allah Swt. dalam setiap mengawali suatu kegiatan yang bermanfaat dengan bacaan basmalah "Bismillahirrohmaanirrohiim"; (3)bersungguh-sungguh dan mengerahkan seluruh kemampuan dalam berkarya; (4) dalam berkarya membutuhkan orang lain sehingga diperlukan usaha memperluas jaringan kerja; (5) melakukan segala sesuatu dengan baik; (6) menyikapi kegagalan secara positif dengan terus berupaya tanpa mengenal lelah dan putus asa; (7) bersikap rendah hati, menunjukkan sikap terbuka terhadap kritik dan saran dari pihak lain; (8) secara terus menerus senantiasa melakukan upaya memperbaiki sesuatu yang sudah ada menjadi lebih baik.

\section{HASIL DAN PEMBAHASAN}

Hasil pelaksanaan kegiatan pengabdian pada masyarakat adalah sebagai berikut:

1) Pelaksanaan Kegiatan Pengabdian Pada Masyarakat Kegiatan ini dilakukan pada tanggal 9 November 2020 sampai dengan 11 November 2020, di Aula Kelurahan Pondok Benda, Tangerang Selatan. Kegiatan tersebut dijabarkan sebagai berikut:

a) Acara diawali dengan pengenalan tentang apa itu Manajemen Kreativitas dalam perekonomian.

b) Kemudian dilanjutkan dengan ceramah tentang Manajemen kreativitas meningkatkan produktivitas.

c) Para peserta diberikan sebuah tayangan yang menggambarkan Trik-trik dan strategi meningkatkan produktivitas.

d) Setelah sesi ceramah dan demonstrasi tayangan, dilanjutkan dengan syaring mengenai Produktivitas.

2. Hasil Kegiatan Pengabdian Kepada Masyarakat Hasil Kegiatan Pengabdian Pada Masyarakat antara lain adalah sebagai berikut:

a) Pada sesi ceramah dibuka kesempatan untuk berdiskusi, di mana melihat pemahaman Masyarakat Kelurahan Pondok Benda. Banyak dari Masyarakat tersebut yang baru pertama kali mendengar istilah Manajemen Kreativitas. Sehingga penjelasan dalam 
Loyalitas Kreativitas

Aldi Masyarakat Kreatif
P-ISSN 2722-2101, E-ISSN 2722-4201

Program Studi Ekonomi Manajemen Universitas Pamulang Jurnal LOKABMAS Kreatif Vol.02,No.01,Maret 2021 Hal. 1-7 Email:jurnalkreatif.manajemen@gmail.com sesi diskusi ini memberikan pengetahuan baru kepada mereka.

b) Sesi ceramah dan diskusi berjalan sangat kondusif, para peserta dengan antusias mengikuti sesi pelatihan Manajemen Kreativitas. Saat demonstrasi video, para peserta memperhatikan dengan seksama.

c) Pada sesi sharing diambil 5 Orang dari Masyarakat untuk menjabarkan Produktivitas yang dilakukan.

\section{KESIMPULAN DAN SARAN \\ Kesimpulan}

Berdasarkan pemaparan hasil pelaksanaan kegiatan pengabdian pada masyarakat dan pembahasannya, maka dapat disampaikan kesimpulan sebagai berikut:

1. Kegiatan PKM ini membuka cakrawala pengetahuan Masyarakat Kelurahan Pondok Benda mengenai konsep Manajemen.

2. PKM ini memungkinkan organisasi untuk menanggapi peluang eksternal atau internal dan menggunakan kreativitas untuk memperkenalkan ide-ide, proses, atau produk yang ditindaklanjuti oleh masyarakat kelurahan Pondok Benda.

3. Produktifitas Masyarakat Kelurahan Pondok Benda mempunyai peranan yang sangat penting dalam meningkatkan kesejahteraan nasional. Tidak ada jenis kegiatan manusia yang tidak mendapatkan keuntungan dari produktivitas yang ditingkatkan sebagai kekuataan untuk menghasilkan lebih banyak barang barang maupun jasa jasa.

\section{Saran}

1. Bagi Masyarakat Umum, Manajemen Kreativitas sangat bermanfaat dengan meningkatkan dari segi pengetahuan dan wawasan, juga pada pengaplikasian dalam kehidupan sehari-hari.

2. Produktivitas penting sekali, karena pendapatan nasional atau GNP banyak diperoleh dengan meningkatkan keefektifan dan tenaga kerja dibandingkan dengan melalui formasi modal dan penambahan kerja. Peningkatan produktivitas juga menghasilkan peningkatan langsung pada standar hidup yang berada dibawah kondisi distribusi yang sama dari perolehan produktivitas yang sesuai dengan masukan tenaga kerja.

\section{DAFTAR PUSTAKA}

Elburdah, R. P., Pasaribu, V. L. D., Rahayu, S., Septiani, F., \& Metarini, R. R. A. (2021). MOMPRENEUR PENOPANG PEREKONOMIAN KELUARGA DI MASA PANDEMI COVID-19 DENGAN BISNIS ONLINE PADA KELURAHAN PONDOK BENDA. Abdi Laksana: Jurnal Pengabdian Kepada Masyarakat, 2(1), 75-82.

Iswandi dan Saiful Amiq, 2013, "Manajemen Keuangan Keluarga I" Artikel Onlinine. https://juraganmakalah.blogspot.com/2013 /03/manajemen-keuangan-keluarga-i.html (Diakses Hari Selasa 6 Oktober 2020)

Kasmir (2010) , Pengantar Manajemen Keuangan. Edisi Kedua, Penerbit: Kencana Prenada Media Group, Jakarta.

Love Life Daily, 2020, "Manajemen Keuangan bagi Lajang dan Keluarga Baru di Era New Normal" Artikel Online https://ilovelife.co.id/blog/manajemenkeuangan-bagi-lajang-dan-keluarga-barudi-era-new-normal/. (Diakses Hari Selasa 6 Oktober 2020).

Gitman, Lawrence, J.(2015). Principles of Manajerial Finance. International Edition, 10th edition, Pearson Education, Baston.

Hasibuan, Malayu S.P. (2012). Manajemen Sumber Daya Manusia. Jakarta: PT.Bumi Aksara.

Priadi, A., Pasaribu, V. L. D., Virby, S., Sairin, S., \& Wardani, W. G. (2020). Penguatan Ekonomi Kreatif Berbasis Sumber Daya Desa Dikelurahan Rempoa. Abdi Laksana: Jurnal Pengabdian Kepada Masyarakat, 1(3), 356-358.

DOKUMENTASI KEGIATAN 
Loyalitas Kreativitas

Aldi Masyarakat Kreatif
P-ISSN 2722-2101, E-ISSN 2722-4201

Program Studi Ekonomi Manajemen Universitas Pamulang Jurnal LOKABMAS Kreatif Vol.02,No.01,Maret 2021 Hal. 1-7 Email:jurnalkreatif.manajemen@gmail.com
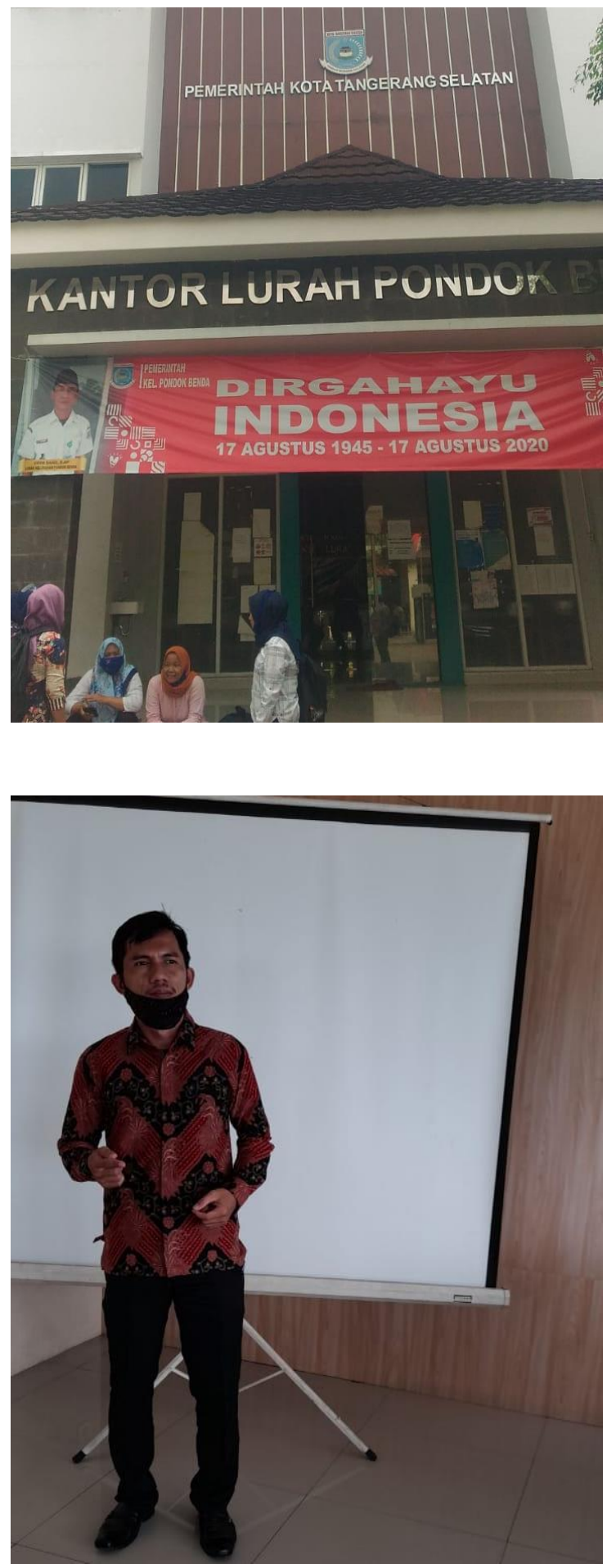
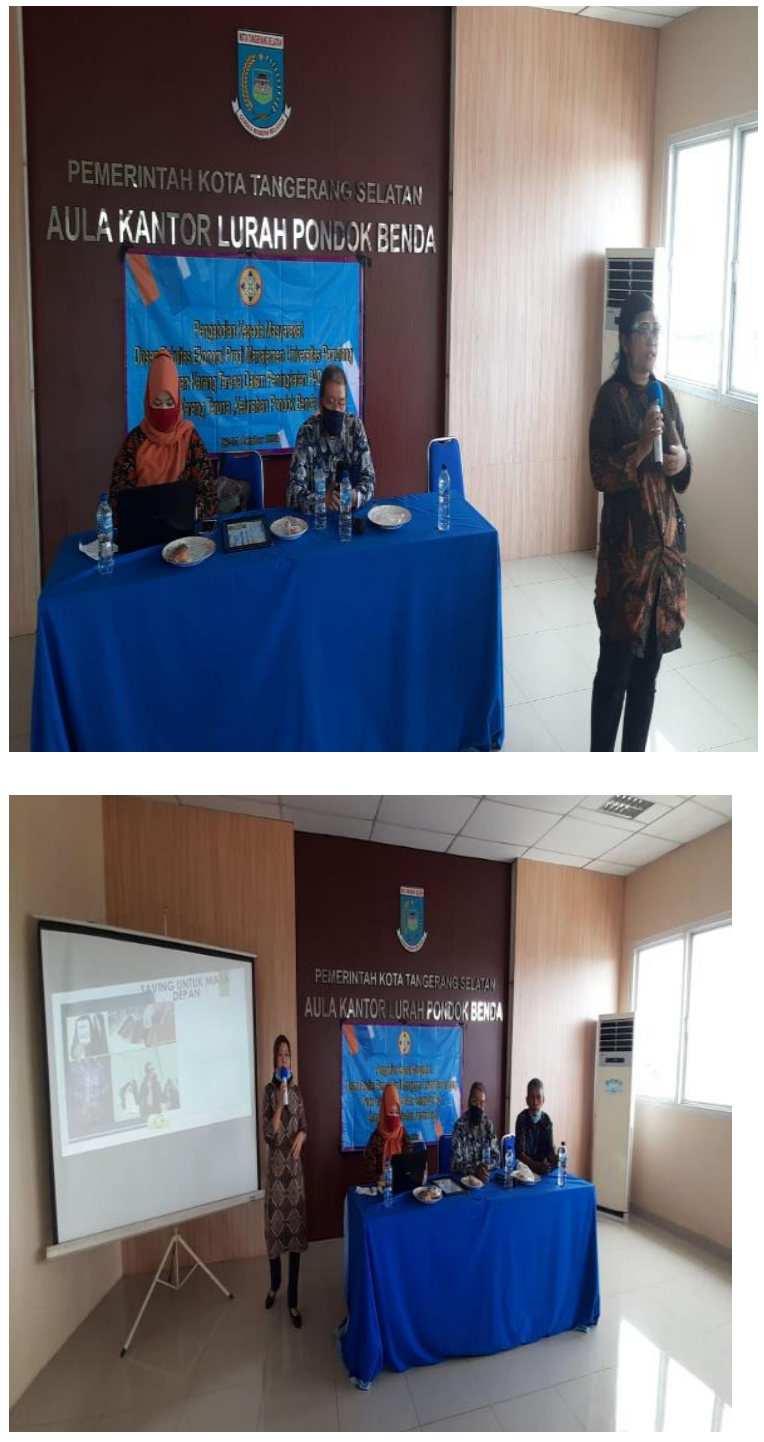